\title{
SYLVATIC TRICHINELLOSIS IN TEXAS
}

\author{
PENCE D.B.*, LA ROSA G.**, MANCINI BARBIERI F.**, \\ AMATI M.**, CASULLI A.** \& POZIO E.**
}

\section{Summary :}

There are no published reports of domestic or sylvatic trichinellosis in Texas. The aim of the present survey was to determine the presence of Trichinella species in selected representative species of potential wildlife reservoirs in southern Texas. In 1998-99, tongues of 211 wild mammals were collected in southern Texas: 154 coyotes (Canis latrans), three bobcats (Lynx rufus), 32 racoons (Procyon lotor), 13 opossum (Didelphis marsupialis), four ocelots (Leopardus pardalis) and five wild boars (Sus scrofa). Presence of Trichinella sp. larvae was investigated by artificial digestion and larvae of positive samples were identified at the species level by a multiple-polymerase chain reaction analysis. Nine $(5.8 \%)$ coyotes had trichinellosis; in the muscles of seven of these coyotes, the larvae were identified as Trichinella murrelli. This is the first report of sylvatic trichinellosis in Texas.

KEY WORDS : Trichinella murrelli, coyotes, Texas.

$\Lambda$ side from anecdotal public health reports of small isolated outbreaks of human trichinellosis in certain communities of the south-central part of Texas (USA), there are no published reports of domestic or sylvatic trichinellosis in this state. The aim of this survey was to determine the presence of Trichinella spp. in selected representative species of potential wildlife reservoirs in southern Texas.

\section{MATERIALS AND METHODS}

In n 1998 and 1999, tongues of wild mammals killed by either hunters or by the Texas Rodent and Predator Control Agency were collected from 13 localities in southern Texas. Tongues were immediately frozen and sent by courier to the International Trichinella Reference Centre in Rome, Italy. A muscle sample of about $3 \mathrm{~g}$ excised from each frozen tongue was used

\footnotetext{
* Department of Pathology, Texas Tech University Health Sciences Center, $36014^{\text {th }}$ Street, Lubbock, Texas 79430, USA.

** Laboratory of Parasitology, Instituto Superiore di Sanità, viale Regina Elena 299, 00161 Rome, Italy.

Correspondence: E. Pozio.

Tel.: + 390649902304 - Fax: + 390649387065 - e-mail: pozio@iss.it
}

to detect specific antibodies against rabies by an immunofluorescence test. With the superficial layers removed, the tongue muscle (ranging from 7 to $70 \mathrm{~g}$ ) was diced into small pieces and digested according to standard procedures (Pozio, 1987). Trichinella sp. larvae were identified to the species level by a multiple-polymerase chain reaction (PCR) analysis according to a published protocol (Zarlenga et al., 1999). The primer set oTsr1 (5'-CGA AAA CAT ACG ACA ACT GC-3') and oTsr4 (5'-GTT CCA TGT GAA CAG CAG T-3') was used. Muscle larvae of reference strains of T. spiralis (code ISS3), T. nativa (ISS10), T. pseudospiralis (ISS13), T. murrelli (ISS35) and Trichinella T6 (ISS34) were used as controls.

\section{RESULTS}

Tongues from 211 mammals were examined (Table I). All samples were negative for rabies (data not shown). Nine (5.8\%) coyotes had trichinellosis. These coyotes came from two neighbouring ranches located in southern Texas at $27^{\circ} 55^{\prime} \mathrm{N}$, $99^{\circ} 10^{\prime} \mathrm{W}$ and at $28^{\circ} 00^{\prime} \mathrm{N}, 99^{\circ} 00^{\prime} \mathrm{W}$, about 60 and $120 \mathrm{~km}$ from the border of Mexico, respectively. The intensity of infection in these coyotes ranged from 0.05 to 0.6 larvae per gram of muscle tissue. Larvae in the

\begin{tabular}{lc}
\hline \multicolumn{1}{c}{ Host } & $\begin{array}{c}\text { Positive/ } \\
\text { Total (\%) }\end{array}$ \\
\hline Coyote (Canis latrans) & $9 * / 154(5.8)$ \\
Raccoon (Procyon lotor) & $0 / 32$ \\
Opossum (Didelphis marsupialis) & $0 / 13$ \\
Ocelot (Leopardus pardalis) & $0 / 4$ \\
Bobcat (Lynx rufus) & $0 / 3$ \\
Feral hog (Sus scrofa) & $0 / 5$ \\
\multicolumn{1}{c}{ Total } & $9 / 211(4.3)$ \\
\hline
\end{tabular}

* Seven coyotes harboured T. murrelli, whereas larvae from two coyotes did not show reproducible results after PCR amplification. The average larvae per gram was 0.2 with a range of $0.6-0.05$.

Table I. - Prevalence of Trichinella infection in carnivores, marsupials and swine from Texas 
muscle of seven coyotes were identified as Trichinella murrelli. Larvae from the tongues of two animals did not show any reproducible result after PCR amplification.

\section{DISCUSSION}

T This is the first report of sylvatic trichinellosis in Texas, extending the southern limit of distribution of T. murrelli to the $28^{\text {th }}$ parallel and suggesting that this species may be present in the wildlife of Mexico, where the presence of sylvatic trichinellosis has never been investigated. Previously to this study, T. murelli had only been detected in eastcoast States of USA (i.e., Connecticut, Georgia, Illinois, Indiana, Pennsylvania) (Pozio \& La Rosa, 2000).

The observed prevalence of infection in coyotes of Texas is apparently low, and the infection was observed only on two ranches, suggesting a focality distribution. However, the prevalence of infection on these ranches was high (i.e., $17.4 \%, 4 / 23$; and $29.4 \%$, $5 / 15)$. In interpreting the results of this study, it must be considered that in only six of the 13 sites was a sufficient number of animals investigated (i.e., from 12 to 48); thus we cannot exclude that Trichinella infection may be widespread in the areas where very few animals were examined (i.e., from one to 9 animals).

With regard to the host species, the results of the present study suggest that the coyote is the main reservoir of sylvatic trichinellosis in the investigated area, although it must be considered that many more coyotes were examined in comparison with other animals. In fact, during the period 1953-1968 in the State of Iowa, the prevalence of Trichinella infection has been reported to be $0.6 \%$ and $0.8 \%$, in racoons and opossums respectively (Zimmermann \& Hubbard, 1969); assuming that there are similar prevalences in Texas, our sample sizes were too small to detect this parasite in these animals.

With respect to human trichinellosis in Texas, in the period 1936-41, Trichinella larvae were detected in $14.3 \%$ of the diaphragms of the 21 cadavers examined (Zimmermann, 1970); however, these persons could have acquired the infection in another State where trichinellosis was a common infection at that time.

The study of the spread of trichinellosis in wildlife in Texas and the neighbouring states of New Mexico, Arizona and California is important because there is no information concerning wildlife trichinellosis in Mexico and Central America, an area that could represent a bottleneck for the dispersion of sylvatic trichinellosis in the Neotropic region.

\section{ACKNOWLEDGEMENTS}

his survey was made possible by the support received from the surveillance project on emerging and re-emerging infectious diseases (Istituto Superiore di Sanità Art.502/12, Ministry of Health of Italy).

\section{REFERENCES}

Pozıo E. Isoenzymatic typing of 23 Trichinella isolates. Tropical Medicine and Parasitology 1987, 38, 111-116.

Pozıo E. \& LA Rosa G. Trichinella murrelli n. sp: etiological agent of sylvatic trichinellosis in temperate areas of North America. Journal of Parasitology, 2000, 86,134-139.

Zimmermann W.J. Trichinosis in the United States. In: Trichinosis in man and animals, S.E. Gould (ed.), C.C. Thomas, Springfield, Illinois, 1970, 378-400.

ZimMERMANN W.J. \& HubBard E.D. Trichiniasis in wildlife of Iowa. American Journal of Epidemiology, 1969, 90, 84-92.

Zarlenga D.S., Chute M.B., Martin A. \& Kapel C.M.O. A multiplex PCR for unequivocal differentiation of six encapsulated and three non-encapsulated genotypes of Trichinella. International Journal for Parasitolology, 1999, 29, 141-149. 